\title{
Phoenix canariensis: Canary Island Date Palm
}

\author{
T. K. Broschat ${ }^{2}$
}

The Canary Island date palm (CIDP) is native to the Canary Islands. Although it can reach heights of $40-50$ feet, it is slow growing and requires many years to attain that height. It has 8- to 15-foot-long rigid leaves that contain up to 200 $\mathrm{V}$-shaped leaflets, the basal ones of which are modified into long, sharp spines (Fig. 1). Healthy specimens should have full, round canopies with 130-150 leaves, but potassium (K) deficiency typically reduces the number of leaves in the canopy to half that number or less. In South Florida, this species produces about 50 leaves per year. Leaves are not self-cleaning and must be manually removed when dead, but the leaf bases eventually rot off, leaving an attractive diamond-shaped pattern of leaf scars on the 2- to 3-footdiameter trunk. On older specimens, the basal foot or so of the trunk typically is covered with short root initials.

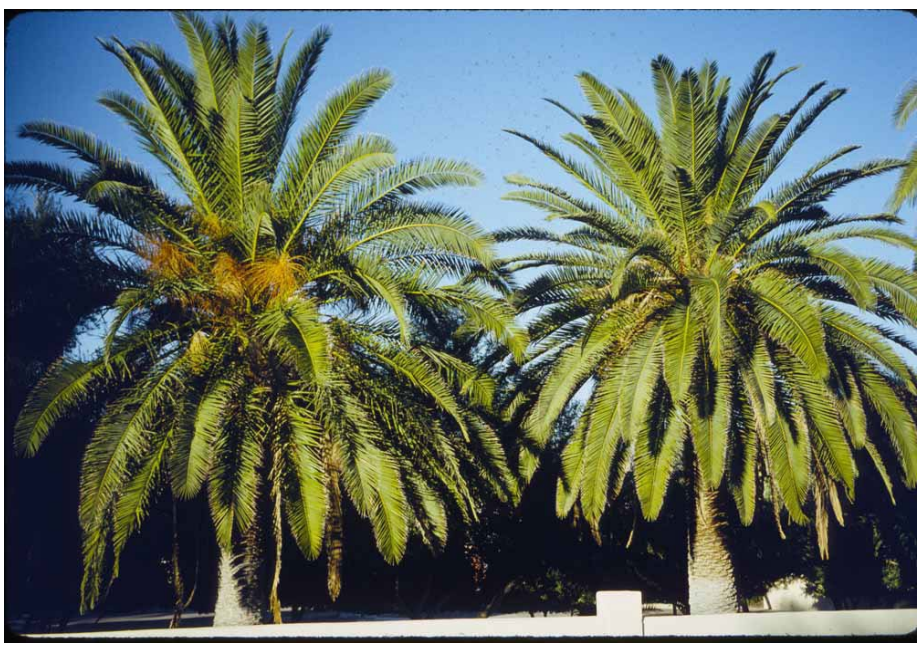

Figure 1. Healthy Canary Island date palms.

Credits: T. K. Broschat
Flower stalks are orange in color, about 3 feet in length, and bear male and female flowers on separate trees. Fruits are orange and edible, though not particularly tasty. Canary Island date palms readily hybridize with other Phoenix species, yielding individuals that vary considerably in their appearance from either parent. Fresh seeds germinate in 2-3 months under high temperatures $\left(85^{\circ} \mathrm{F}-95^{\circ} \mathrm{F}\right)$ and uniform moisture.

Canary Island date palms are grown throughout the warmer parts of the United States from USDA Hardiness Zones 9A-11 (> 20 $\mathrm{F}$ ) (http://planthardiness.ars.usda.gov/ PHZMWeb/). They can be grown on a wide range of soil types, with their primary requirement being good drainage. They are drought tolerant and moderately tolerant of salt spray.

\section{Transplanting Canary Island Date Palms}

Transplanting CIDP is no different from other species, with root balls of 2-3 feet from the trunk being typical. About half to two-thirds of the lower leaves should be removed at the time of digging to reduce water loss and facilitate handling. The remaining leaves should be tied in a tight bundle with a long wooden splint attached to the trunk and the leaf bundle to prevent the crown from snapping off during handling (Fig. 2). Because CIDP wood is very soft, physical damage to the bud area can easily occur during handling and may be responsible for transplant failure rates of up to $35 \%$ in this species. Make sure that the palm's crown is fully supported when placed on a truck or trailer to prevent bud

1. This document is ENH-598, one of a series of the Environmental Horticulture Department, UF/IFAS Extension. Original publication date November 1993. Revised August 2013. Visit the EDIS website at http://edis.ifas.ufl.edu. 
damage. For more information about transplanting palms, see Transplanting Palms in the Landscape (http://edis.ifas. ufl.edu/ep001).

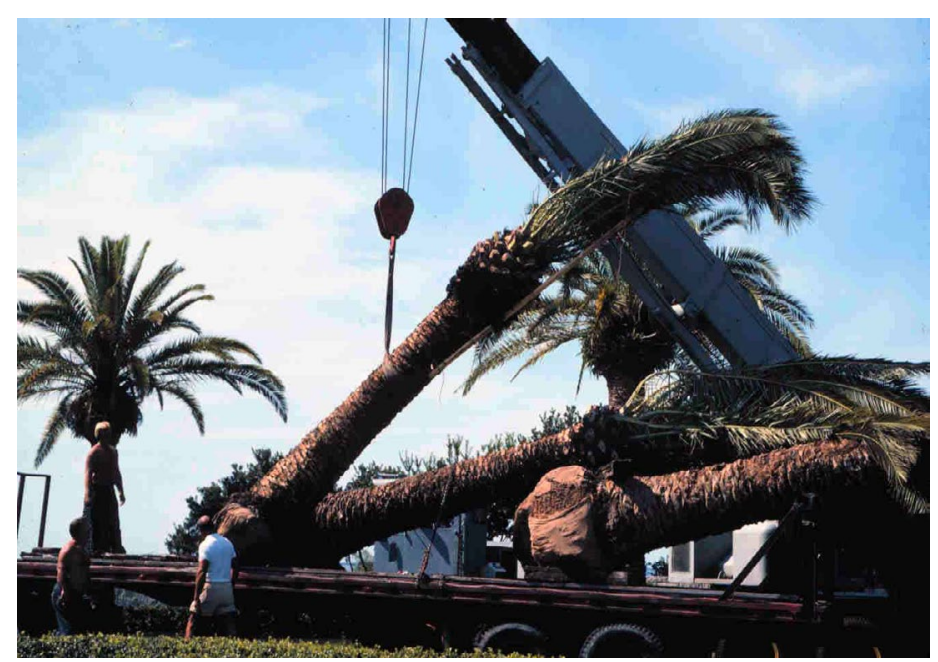

Figure 2. Proper handling of Canary Island date palm. Credits: T. K. Broschat

\section{Management in the Landscape}

Canary Island date palms are highly susceptible to $\mathrm{K}$ and magnesium $(\mathrm{Mg})$ deficiencies under landscape conditions. Potassium deficiency symptoms appear as translucent light green to yellow and necrotic spotting on the oldest leaves. As the deficiency progresses, leaflet tip necrosis becomes the predominant symptom. These necrotic leaflet tips are quite brittle and usually break off, leaving the distal portions of K-deficient leaves with irregular margins (Fig. 3). Potassium deficiency symptoms are most severe toward the tips of the oldest leaves, with younger leaves and basal leaflets of all leaves showing few or no symptoms. Potassium deficiency also causes premature loss of older

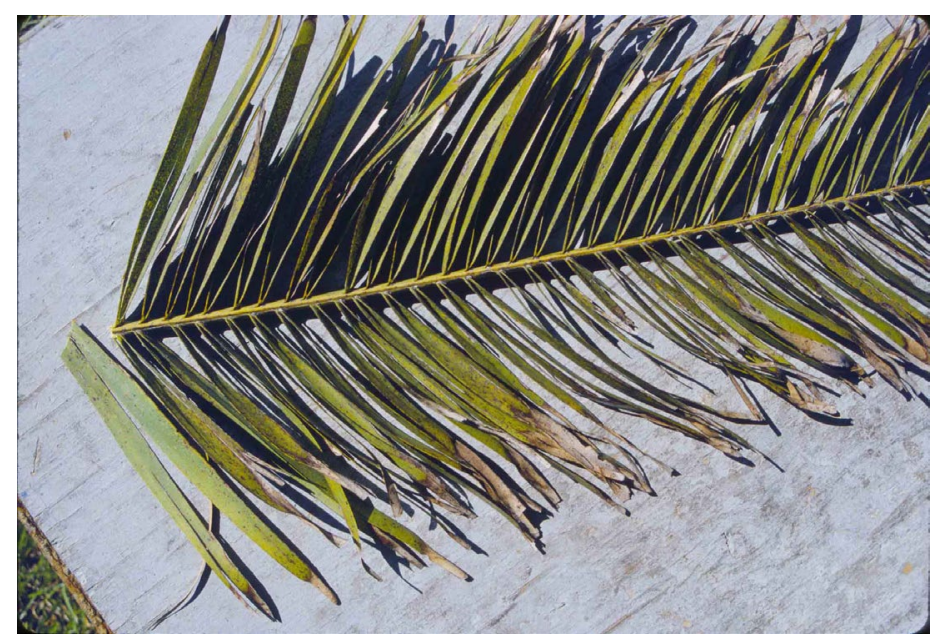

Figure 3. Potassium-deficient older leaf tip of Canary Island date palm. Credits: T. K. Broschat leaves, resulting in a canopy of many fewer leaves than is normal for the species. Because K-deficient older leaves are unsightly, they are often trimmed off. This is not recommended since these symptomatic older leaves are actually serving as a supplemental source of $\mathrm{K}$ for the tree in the absence of sufficient $\mathrm{K}$ in the soil. Proper fertilization to alleviate $\mathrm{K}$ deficiency symptoms is the best solution to the problem.

Most Canary Island date palms growing in the Southeast have some degree of $\mathrm{K}$ deficiency, but some also show striking lemon yellow bands along the outer margins of otherwise green older leaves. These symptoms are characteristic of $\mathrm{Mg}$ deficiency. When both $\mathrm{K}$ and $\mathrm{Mg}$ deficiencies exist on the same palm, the oldest (lowest) leaves show $\mathrm{K}$ deficiency symptoms, and the mid-canopy leaves display Mg deficiency symptoms (Fig. 4). Transitional leaves have Mg-deficient bases and K-deficient tips (Fig. 5). Canary Island date palms in the Southeast should be fertilized three times per year (four times in South Florida) with an $8-2-12-4 \mathrm{Mg}$ plus micronutrients palm fertilizer that has $100 \%$ of its nitrogen, $\mathrm{K}$, and $\mathrm{Mg}$ in controlled-release form and its micronutrients, such as iron and manganese, in water-soluble sulfate or chelated (iron only) form. See Fertilization of Field-grown and Landscape Palms in Florida (http://edis.ifas.ufl.edu/ep261) for more information.

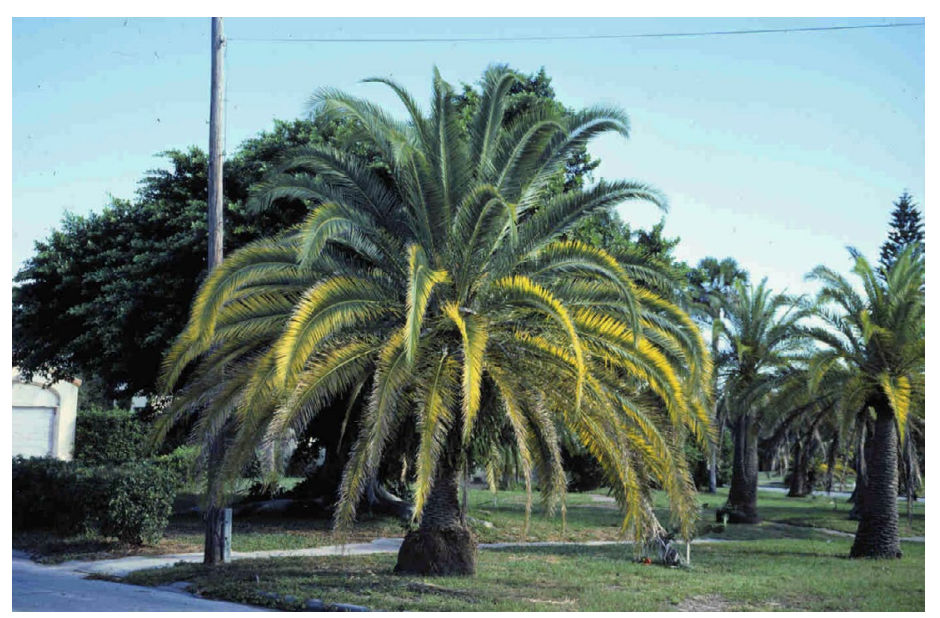

Figure 4. Canary Island date palm showing potassium and magnesium deficiencies.

Credits: T. K. Broschat 


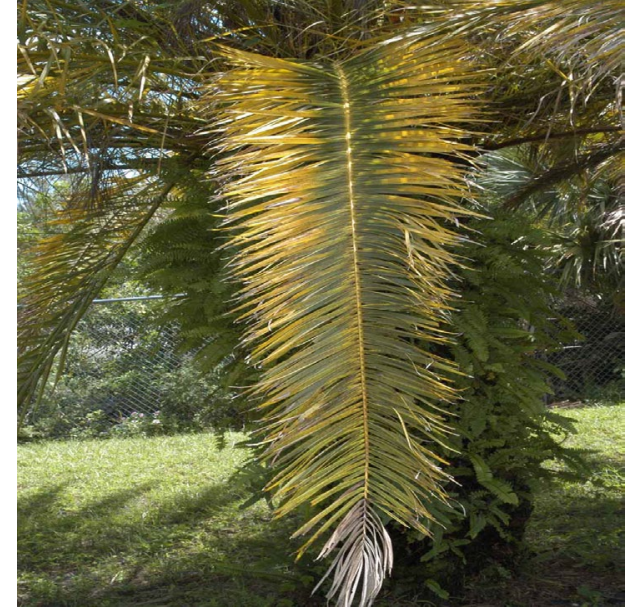

Figure 5. Transitional leaf showing potassium deficiency (tip) and magnesium deficiency (base) symptoms.

Credits: T. K. Broschat

\section{Pests and Diseases of Canary Island Date Palms}

Canary Island date palms are highly susceptible to palmetto weevils (Rhynchophorus cruentatus) (http://edis. ifas.ufl.edu/in139), which lay their eggs in the petioles of the older leaves. The larvae burrow into the heart of the palm, eventually killing it (Figs. 6 and 7). These weevils are particularly attracted to volatile chemicals emitted by stressed or wounded CIDP, which can attract weevils from up to half a mile away. Leaf removal during pruning and transplanting operations is a primary cause of palmetto weevil infestations. Insecticidal treatments of cut leaf surfaces is recommended for transplanted CIDP. The practice of trimming CIDP leaves into a "pineapple" shape is highly discouraged, not only because it removes leaves needed for K nutrition, but because these cut leaf wounds are strong attractants for palmetto weevils. The smaller silky cane weevil (Metamasius hemipterus) (http://edis. ifas.ufl.edu/in210) also attacks CIDP, but these weevils tend to remain in the leaf bases and do not kill the palm by themselves. However, the wounds they create in the leaf bases attract the more destructive palmetto weevils that can ultimately kill the tree (Fig. 8).

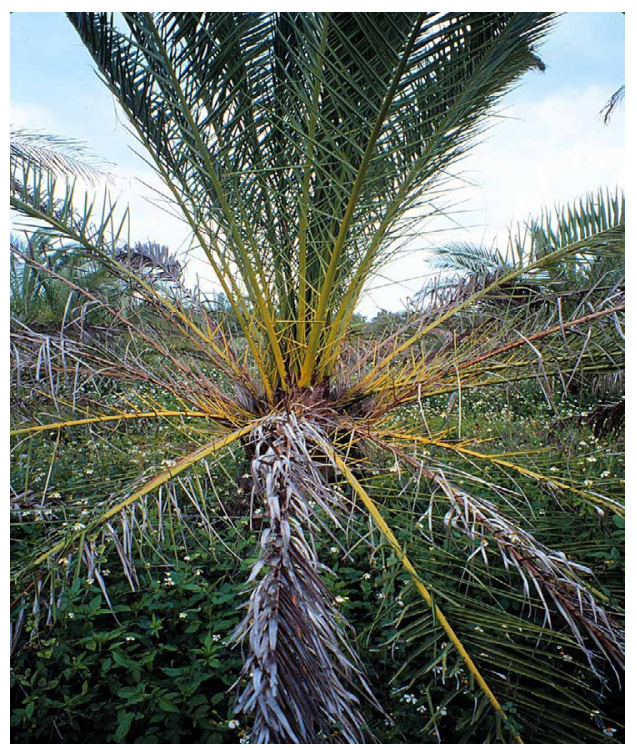

Figure 6. Canary Island date palm infested with palmetto weevils. Credits: R. Giblin-Davis

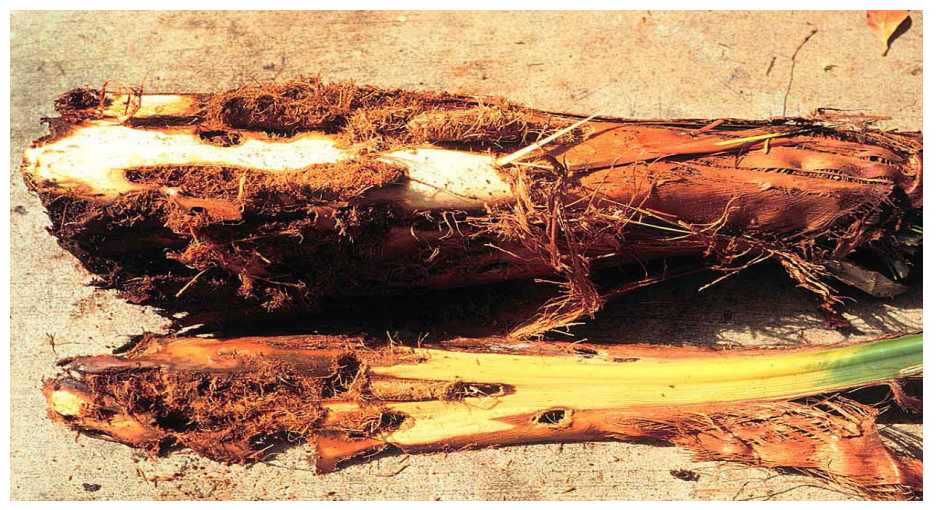

Figure 7. New leaves infested with palmetto weevil cocoons. Credits: R. Giblin-Davis

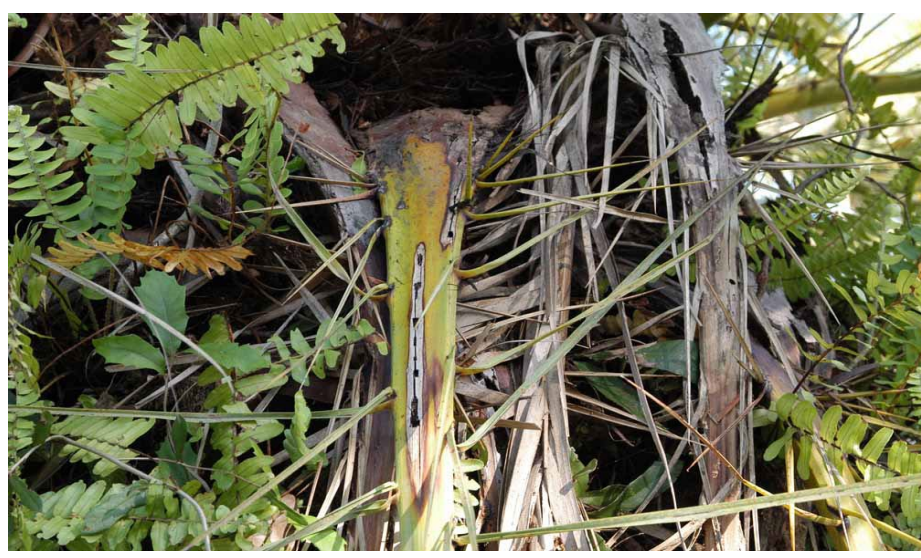

Figure 8. Canary Island date palm petioles showing damage caused by silky cane weevils.

Credits: T. K. Broschat 
Canary Island date palms are susceptible to a number of diseases, most of which are lethal. One disease that is mostly cosmetic in its effect is Graphiola leaf spot, commonly known as "false smut." The fungus, Graphiola phoenicis, produces small $(<1 / 16$ inch) brown to black spots on both surfaces of the leaflets on the oldest leaves (Fig. 9). The symptoms of Graphiola leaf spot are commonly confused with those of $\mathrm{K}$ deficiency, which also causes spotting on the oldest leaves. Eventually, reproductive structures called "sori" erupt from the spots, producing small, thread-like structures that can easily be felt when rubbing a finger across the leaflet. Some literature suggests that this disease causes premature senescence of older leaves, but this is more likely caused by $\mathrm{K}$ deficiency, which is typically present on the same leaves. Treatment of this disease may not be warranted in a landscape situation since it requires multiple applications of fungicides to control, and the disease appears to do little harm to the palm. For more information, see Graphiola Leaf Spot (False Smut) of Palm (http://edis.ifas.ufl.edu/pp140).

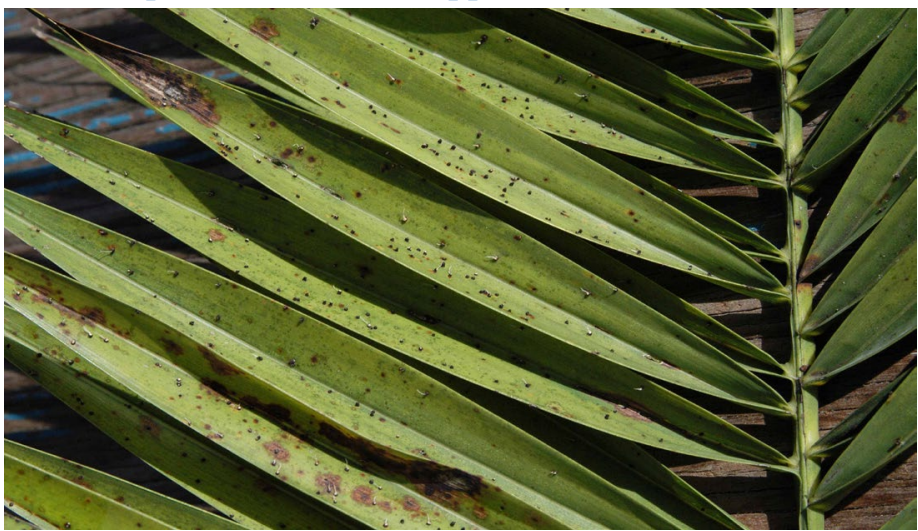

Figure 9. Canary Island date palm leaf with Graphiola leaf spot. Larger brown lesions are caused by Stigmina leaf spot.

Credits: T. K. Broschat

Fusarium wilt (caused by the fungus Fusarium oxysporum $\mathrm{f}$. sp. canariensis) is one of the most serious diseases of CIDP (Fig.10). Early symptoms appear as necrosis of the leaflets on one side of the rachis (Fig.11). This is usually accompanied by a reddish-brown strip on the affected side of the rachis and petiole (Fig. 12). Eventually, the entire leaf dies. Symptoms usually begin on the oldest leaves and progress upward, leaving a skirt of dead leaves at the bottom of the canopy. Eventually, the palm dies. In this species, the disease is primarily transmitted by infested pruning tools, which spread the disease from one CIDP to another (Fig. 13). Development of initial symptoms in the middle of the canopy is associated with pruning of flower and fruit stalks with infested pruning tools. There are no known chemical controls for this disease, but the rate of spread can be greatly reduced by disinfecting pruning tools between trees and avoiding trimming any leaves that are not completely dead. See Fusarium Wilt of Canary Island Date Palm (http:// edis.ifas.ufl.edu/pp139) for more information.

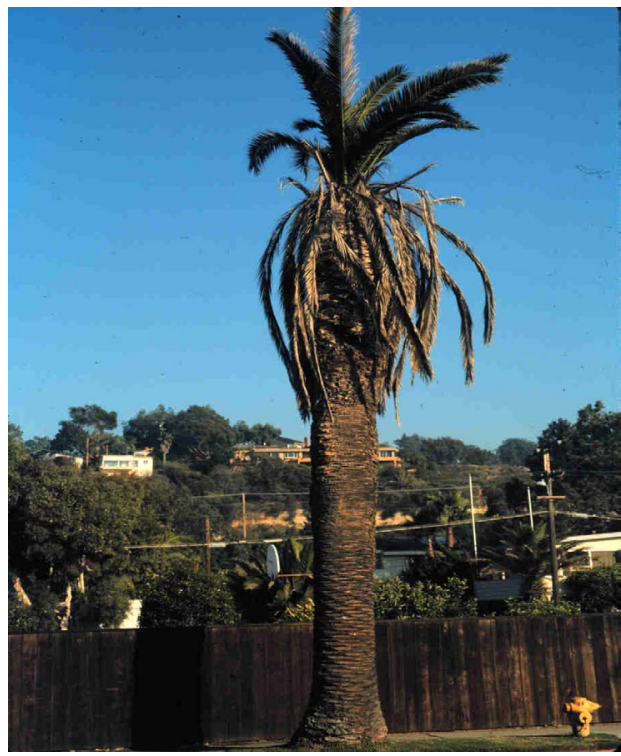

Figure 10. Canary Island date palm infected with Fusarium wilt. Credits: T. K. Broschat

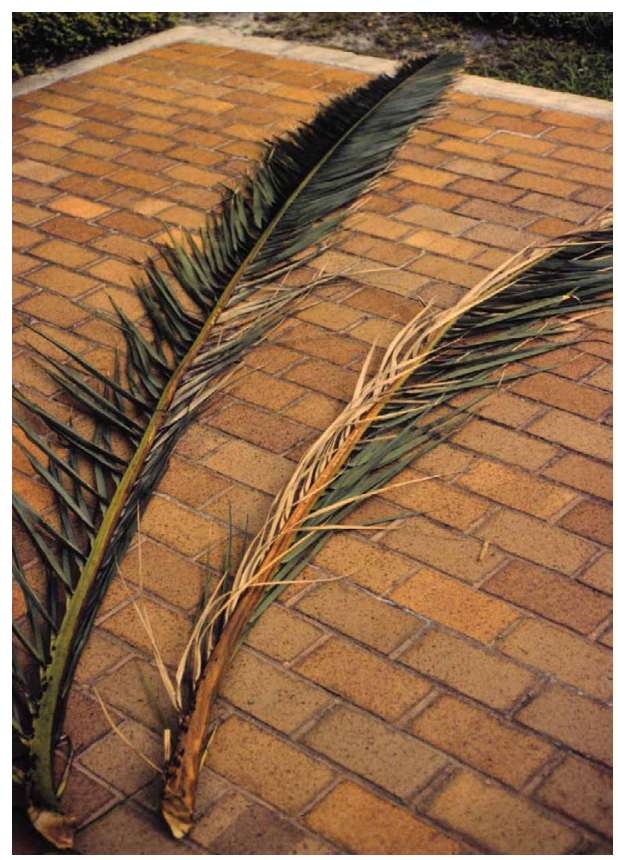

Figure 11. Canary Island date palm leaf showing leaflet necrosis on one side of the rachis.

Credits: T. K. Broschat 


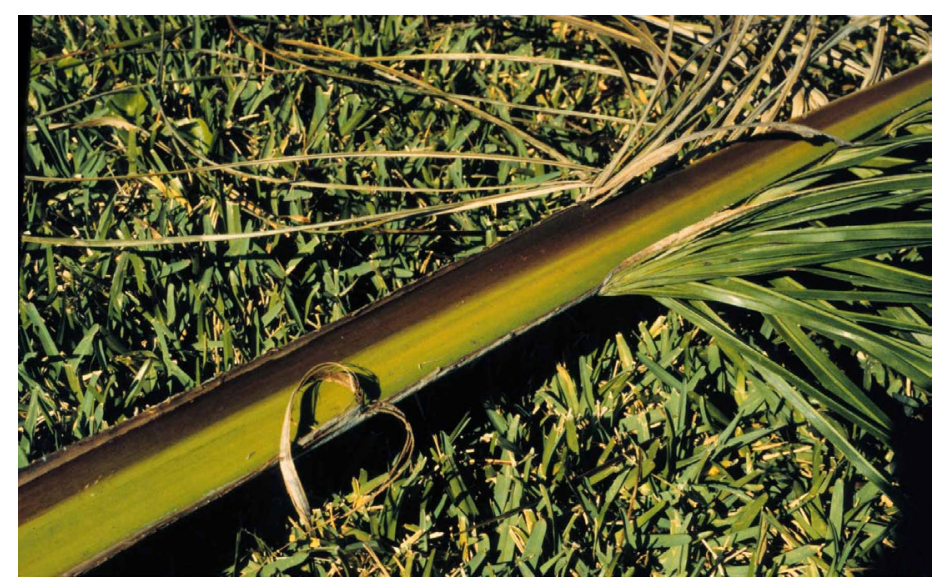

Figure 12. Canary Island date palm leaf showing reddish-brown stripe on one side of the petiole.

Credits: M. L. Elliott

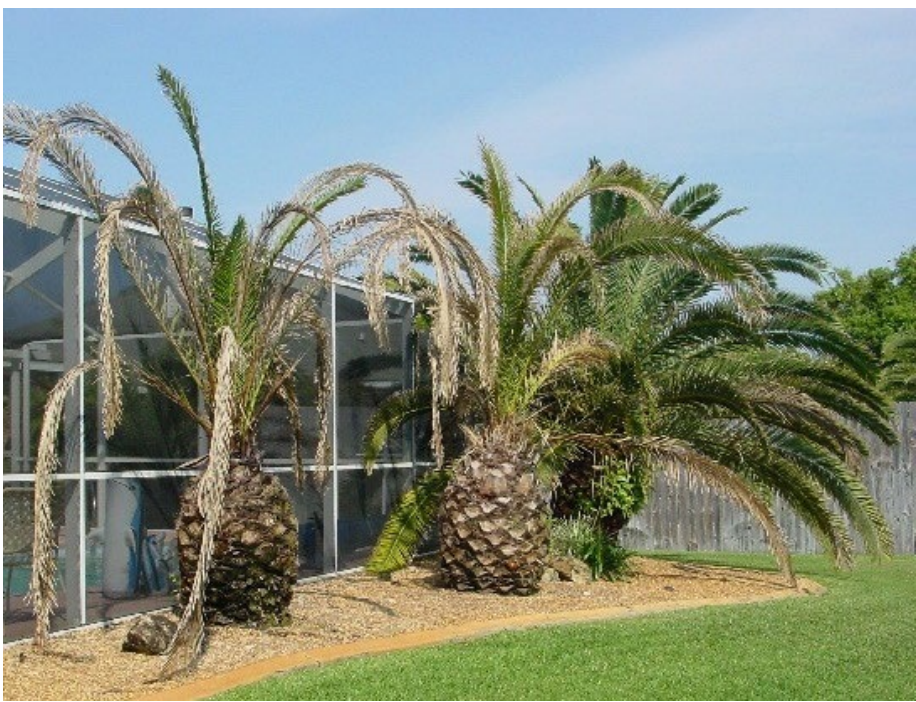

Figure 13. Canary Island date palms dying from Fusarium wilt spread by infested pruning tools.

Credits: M. L. Elliott

Petiole/rachis blight is a nonlethal disease with similar symptoms to Fusarium wilt. It also causes necrosis of the leaflets on one side of the rachis and a reddish-brown stripe on the petiole. While it causes premature leaf loss, this disease usually does not kill palms. Petiole/rachis blight can be caused by many different fungi, but especially Serenomyces. Chemical control of this disease has generally been ineffective, but fortunately, it appears to be seasonal. For more information, see Petiole (Rachis) Blight of Palm (http://edis.ifas.ufl.edu/pp145).

There are two trunk rot diseases of CIDP. The first, Ganoderma butt rot, is caused by the fungus Ganoderma zonatum. This fungus is soilborne and infects the base of the trunk of mature palms, causing a central discoloration and rot within the bottom 3-4 feet. Once about 80\%-90\% of the cross-sectional area has been killed, older leaves will begin to die. The palm may show wilt symptoms before dying (Fig. 14). Shelf-like fruiting structures called "conks" may protrude from the trunk. These conks emerge whitish and look like hard marshmallows, but eventually develop into a shelf with characteristic reddish-brown tops and white bottoms. A single conk can produce over a pint of reddish-brown, dust-like spores that are easily dispersed by the wind. Conks are not always produced, which makes disease diagnosis difficult. There is no way to cure or prevent this disease, and there are no known environmental factors that favor or discourage it. See Ganoderma Butt Rot of Palm (http://edis.ifas.ufl.edu/pp100) for more information.

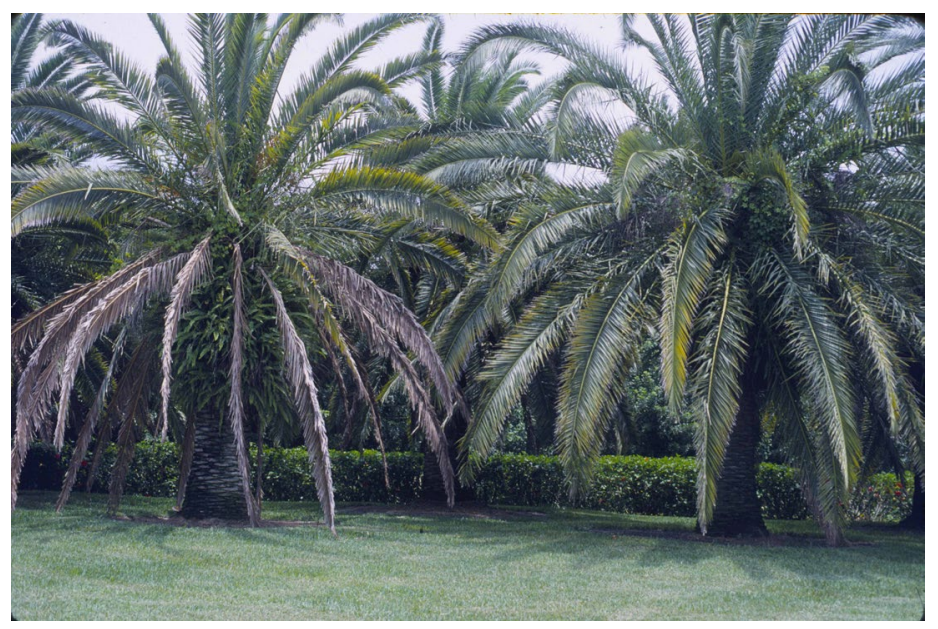

Figure 14. Canary Island date palm on left showing symptoms of Ganoderma butt rot.

Credits: M. L. Elliott

While Ganoderma butt rot affects the basal portion of palm trunks, another disease, Thielaviopsis trunk rot, causes a soft rot and crown collapse in the upper part of the trunk. This disease is caused by the fungus Thielaviopsis paradoxa, which requires a physical wound in the softer upper part of the trunk for infection to occur. Symptoms of this disease may include oozing and fermented trunk lesions, followed by wilting of the canopy, and ultimately canopy collapse

(Fig. 15). Unfortunately, this collapse is not always preceded by visible trunk symptoms or wilting of the foliage, so there may be no warning that the palm is about to fail. Although there are no chemical controls for this disease, simply preventing trunk wounding and limiting leaf removal to dead leaves largely eliminates the chances of a palm becoming infected. Wounds favored by this fungus may be caused by pruning, pulling off old leaves prematurely, climbing spikes, and rough handling during transplanting. See Thielaviopsis Trunk Rot of Palm (http://edis.ifas.ufl.edu/pp143) for more information. 


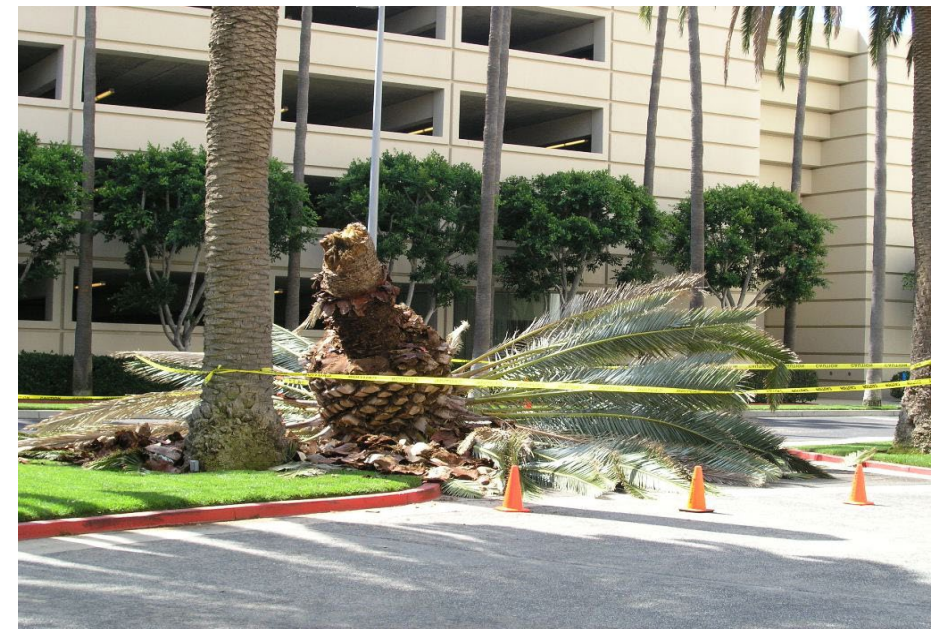

Figure 15. Canopy collapse in Canary Island date palm infected with Thielaviopsis trunk rot.

Credits: H. M. Donselman

Two closely related diseases with identical symptoms are lethal yellowing (LY) and Texas Phoenix palm decline (TPPD). Both diseases are caused by phytoplasmas that require phloem-feeding insect vectors for transmission. Symptoms in this species begin as flower or fruit abortion (only during spring or summer months), followed by premature death of older leaves. When about one-third of the lower leaves have died, the spear leaf dies, with the remaining leaves dying thereafter (Fig. 16). Lethal yellowing on CIDP is found only in South Florida within the United States, but TPPD is found in southern Texas and West Central Florida. Both diseases can be prevented by injecting the trunk three times per year with the antibiotic oxytetracycline. For more information, see Lethal Yellowing (LY) of Palm (http://edis.ifas.ufl.edu/pp146) and Texas Phoenix Palm Decline (http://edis.ifas.ufl.edu/pp163)

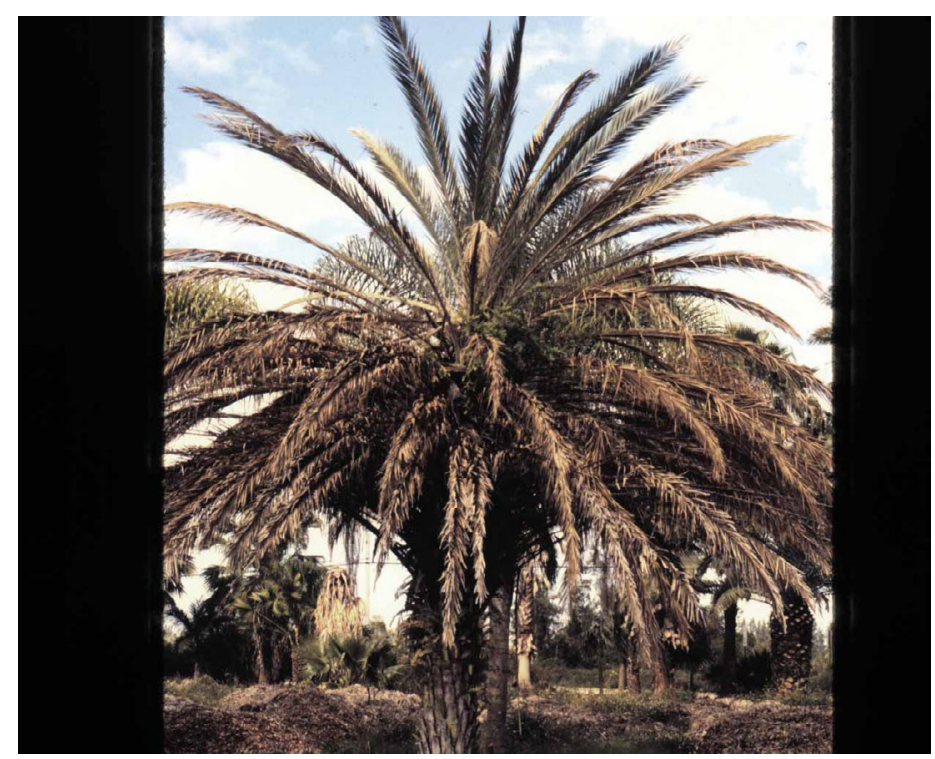

Figure 16. Lethal yellowing on Canary Island date palm. Credits: N. Harrison

\section{References}

Broschat, T. K. 1997. "Nutrient Distribution, Dynamics, and Sampling in Coconut and Canary Island Date Palms." J. Amer. Soc. Hort. Sci. 122: 884-890.

Elliott, M. L., T. K. Broschat, J. Y. Uchida, and G. W. Simone. 2004. Compendium of Diseases and Disorders of Ornamental Palms. St. Paul, MN: American Phytopathological Society.

Meerow, A. W. 2006. Betrock's Landscape Palms. Hollywood, FL: Betrock Info. Systems. 